\title{
Leaf water relations for 23 angiosperm species from steppe grasslands and associated habitats in Hungary
}

\author{
D. $\operatorname{Krasser}^{1}$ and T. Kalapos ${ }^{2}$
}

\author{
Department of Plant Taxonomy and Ecology, L. Eötvös University, Ludovika tér 2., H-1083 Budapest, \\ Hungary; Fax: +36-1-333-8764,E-mail: kalapos@ludens.elte.hu \\ ${ }^{1}$ Current address: Institute of Ecology and Botany, Hungarian Academy of Sciences, Alkotmány u. 4., \\ H-2163 Vácrátót, Hungary, Fax: +36-28-360-110,E-mail: krasser@botanika.hu \\ ${ }^{2}$ Corresponding author.
}

Keywords: Leaf water potential, Osmotic potential, Pressure - volume analysis, Specific leaf area, Steppe grassland.

\begin{abstract}
Pressure-volume (p-V) analysis, instantaneous transpiration rate and relevant leaf structural information were used to compare leaf water relations for 23 angiosperm species from semiarid temperate loess-, sand- and saline steppe grasslands and several associated habitats representing a water availability gradient. For the species studied, the most marked differences occurred between grasses and dicots. Grasses in our survey possessed low (highly negative) osmotic potential both at water saturation and at turgor loss, moderate transpiration rate, relatively high leaf dry matter proportion (DMP) and - except for the sclerophyllous Festuca species - high specific leaf area (SLA, area per unit dry mass). In contrast, dicots had lower bulk tissue elasticity, higher (less negative) osmotic potentials, intense transpiration, and lower SLA and DMP than grasses. Therefore, grasses mainly invest in osmotic potential to extract water from drying soil, while dicots rely on relatively inelastic tissue that decreases water potential by a rapid drop of turgor with turgor loss occurring at relatively high water content. Habitat effects were significant for osmotic parameters only. Osmotic potential at full turgor and at turgor loss decreased in the following order: loess grassland $>$ sand grassland $\cong$ saline grassland $>$ loess wall. Life form influenced leaf structure only, since annuals possessed markedly higher SLA and lower DMP than perennials. Comparison of habitat specialist species within the same genus revealed that certain congeners (Achillea and Aster spp.) do not differ significantly in leaf water relations, thus they might rely on similar water supply in the three steppes. Other congeners (Festuca, Kochia and Plantago spp.) differed considerably, thus for these plants leaf function and structure must be different to ensure survival under the contrasting water regime. For the two generalist grasses (Cynodon dactylon and Dactylis glomerata) habitat-specific populations showed a tendency of increasing capacity for water extraction from soil (more negative water potential) with increasing habitat dryness, although differences were significant only between the extremes of the water availability gradient.
\end{abstract}

Abbreviations: E - potential transpiration rate, DMP - leaf dry matter proportion, ${ }^{0} \mathrm{RWC}$ - relative water content at turgor loss SLA - specific leaf area, $\varepsilon_{i}$ - bulk modulus of elasticity, $\Psi_{\mathrm{p}}$ - turgor potential, $\Psi_{\mathrm{w}}$ - water potential, $\Psi_{\pi}$ - osmotic potential, ${ }^{100} \Psi_{\pi}$ osmotic potential at full turgor, ${ }^{0} \Psi_{\pi}$ - osmotic potential at turgor loss, $\Delta \Psi_{\pi}$ - the amplitude of osmotic response $\left({ }^{100} \Psi_{\pi}-{ }^{0} \Psi_{\pi}\right)$.

\section{Introduction}

Under the semiarid temperate climate of the Hungarian Plain, natural steppe habitats experience various degrees of temporary water shortage depending on local conditions. Soil properties, particularly parent material, texture and ionic composition appear to be an important determinant, since water deficit increases in the direction of loess-, sand- and saline steppe grasslands (Fekete et al. 1997). These communities possess their own characteristic flora (Soó 1964, Varga 1998, Zólyomi and Fekete 1994), where often the same genus is represented by dif- ferent species in different steppe vegetation. Several species, however, seem to be of wider ecological tolerance since they appear in more than one type of these habitats. Among other plant traits (dispersal, life history, ionic tolerance, etc.) water relations certainly play an important role in making species capable of inhabiting one or the other type of these habitats. To test this assumption we compared leaf water relations for congeneric or closely related plant species occurring in only one of the above three grassland types or certain associated steppe habitats ('specialists'), and also for two grass species growing in all three habitats ('generalists'). For this purpose, the 
Table 1. The list of species studied.

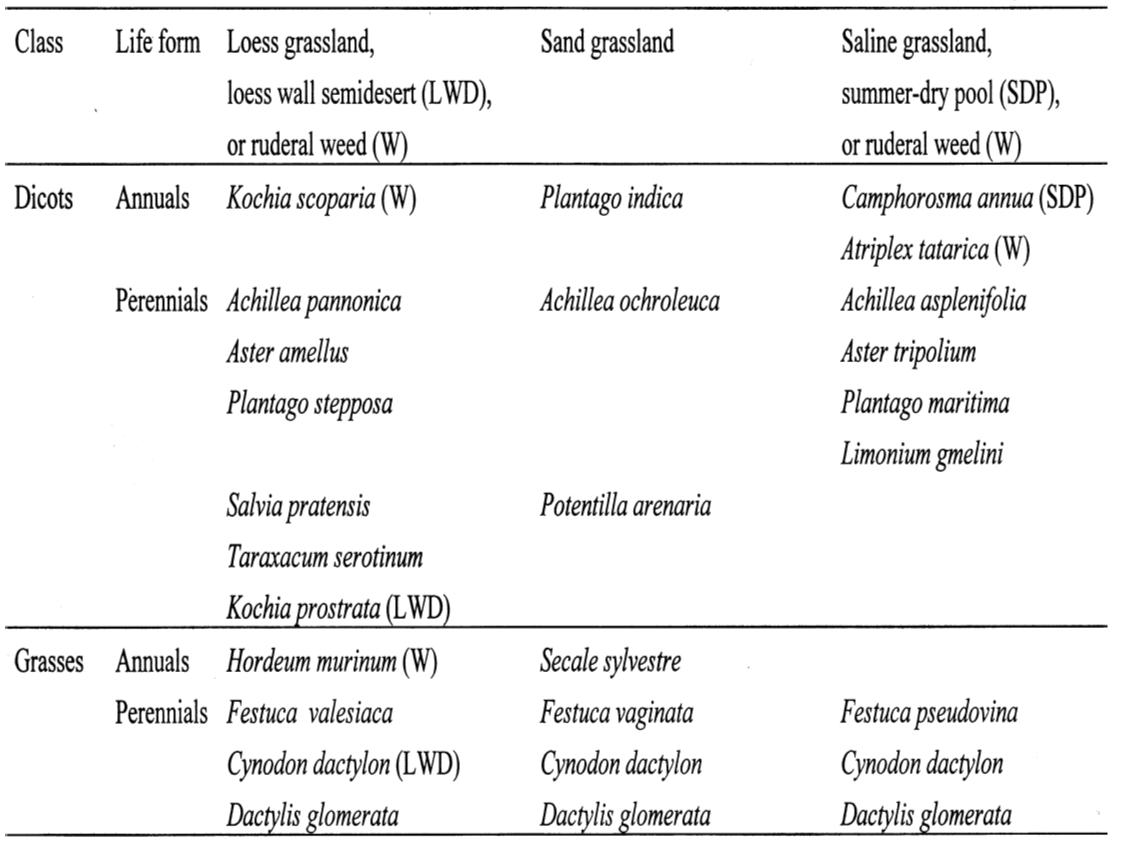

standard procedure of pressure-volume $(\mathrm{p}-\mathrm{V})$ analysis was used. This method has been successively applied to explore differences in leaf water relations between sympatric species (e.g., LoGullo and Salleo 1988, Muller 1991, Nobel and Jordan 1983), genotypes (e.g., Rascio et al. 1988), or seasons with different water regime (e.g., Bowman and Roberts 1985ab, Grammatikopoulos 1999, Knapp 1984, Pavlik 1984, Prior and Eamus 1999, Tyree et al. 1978, Wan et al. 1993). However, we are not aware of a study that compares similar vegetation types along a water availability gradient involving a number of species. Using different techniques, Kvet and Rychnovská (1965) explored leaf water relations for a number of Central European steppe plants. In addition to interspecific and between-site comparisons, we were also curious whether rough taxonomic affiliation (dicot or grass) and life form (annual or perennial) have measurable influence on leaf water relations and associated structural characteristics.

\section{Materials and methods}

Plants were collected on the Great Hungarian Plain in their original steppe habitat from June to August 1997. Sampling mainly focused on three natural steppe grassland associations characteristic of the region: Salvio-Festucetum rupicolae (on loess), Festucetum vaginatae danubiale (on sand), and Achilleo-Festucetum pseudovinae (on saline soil). Few species were collected from other phytocoenoses commonly associated with these grasslands, i.e., Agropyro-Kochietum prostratae (loesswall semidesert), Camphorosmetum annuae (halophyte vegetation in summer-dry saline pools), and ruderal weed associations. Altogether 23 plant species were studied: 16 dicot and 7 grass species, 18 of these were perennial $(\mathrm{H})$ and 5 annual (Th). Each species was from one habitat only except the two generalist grasses (Cynodon dactylon and Dactylis glomerata), which were collected from all three types of steppe. The species studied are listed in Table 1.

\section{Water relations parameters}

In the field, the most recent fully expanded leaves were cut from several shoots per population and were transferred to laboratory in closed chambers with the leaf base immersed in water. Before measurement, at least 12 hours were allowed for leaves to reach full turgor. Then, pressure-volume $(\mathrm{p}-\mathrm{V})$ analysis was performed by repeatedly measuring water potential $(\Psi)$ and mass $(\mathrm{m}$, for relative water content determination) on leaf samples slowly losing their water content in the hygrometer sample chamber which was repeatedly opened up for weighing. Water potential was measured hygrometrically by using a Wescor HR-33T psychrometer/hygrometer connected to eight C52-SF sample chambers (Wescor Inc., Logan, Utah). At least four hours were allowed between consecutive measurements thus leaf samples could equilibrate with chamber air. Mass was measured with $0.1 \mathrm{mg}$ accuracy by using a Kern 410 electronic analytical balance (Kern Inc., Japan). For each species, three replicate $\mathrm{p}-\mathrm{V}$ analyses were conducted. A logarithmic regression was fitted to each $1 / \Psi$ vs. (100-RWC) data set (type II trans- 
Table 2. Leaf water relations and leaf structural parameters for the species groups studied. Abbreviations: ${ }^{100} \Psi_{\pi}:$ osmotic potential at full turgor; ${ }^{0} \Psi_{\pi}$ : osmotic potential at turgor loss; $\Delta \Psi_{\pi}$ : the amplitude of osmotic response $\left({ }^{100} \Psi_{\pi^{-}}{ }^{0} \Psi_{\pi}\right) ;{ }^{0} \mathrm{RWC}$ : relative water content at turgor loss, $\varepsilon_{\mathrm{i}}$ : bulk modulus of elasticity; E: potential transpiration rate; SLA: specific leaf area; DMP: leaf dry matter proportion. For more details see text. For each grouping, values in a column followed by the same letter are not significantly different (ANOVA with LSD test).

\begin{tabular}{|c|c|c|c|c|c|c|c|c|}
\hline group & $\begin{array}{l}100 \Psi_{\pi} \\
(\mathrm{MPa}) \\
\end{array}$ & $\begin{array}{c}{ }^{4}{ }_{\pi} \\
(\mathrm{MPa})\end{array}$ & $\begin{array}{l}\Delta \Psi_{\pi} \\
(\mathrm{MPa})\end{array}$ & $\begin{array}{l}{ }^{\mathrm{R} W C} \\
(\%) \\
\end{array}$ & $\begin{array}{c}\varepsilon_{i} \\
(\mathrm{MPa}) \\
\end{array}$ & $\begin{array}{c}E \\
\left(\mathrm{~g} \mathrm{~m}^{-2} \min ^{-1}\right)\end{array}$ & $\begin{array}{c}\text { SLA } \\
\left(\mathrm{m}^{2} \mathrm{~kg}^{-1}\right)\end{array}$ & DM \\
\hline & $-1.58^{2}$ & $-2.93^{\mathrm{a}}$ & $1.35^{2}$ & $73.2^{\mathrm{a}}$ & $7.96^{\mathrm{a}}$ & & $18.8^{\mathrm{a}}$ & $27.0^{2}$ \\
\hline iots & & $-1.91^{b}$ & $0.79^{b}$ & $78.5^{b}$ & $11.11^{b}$ & & $15.7^{b}$ & $17.6^{6}$ \\
\hline & $-1.00^{2}$ & $-1.70^{\mathrm{a}}$ & $0.70^{2}$ & $75.6^{\mathrm{a}}$ & $8.55^{2}$ & 4.35 & $19.1^{\mathrm{a}}$ & $21.5^{2}$ \\
\hline - & $-1.40^{b}$ & $-2.75^{b}$ & $1.35^{b}$ & $74.7^{\mathrm{a}}$ & $9.23^{\mathrm{a}}$ & 4.07 & $17.2^{\mathrm{a}}$ & $23.0^{\circ}$ \\
\hline aline grassland & $-1.35^{b}$ & $-2.48^{b}$ & $1.12^{2 b}$ & $77.5^{\mathrm{a}}$ & $11.50^{\mathrm{a}}$ & $3.54^{\mathrm{a}}$ & $15.1^{\mathrm{a}}$ & $19.2^{2}$ \\
\hline Ress wall & $-2.12^{c}$ & $-2.97^{\mathrm{b}}$ & $0.86^{a b}$ & $80.2^{\mathrm{a}}$ & $10.11^{\mathrm{a}}$ & $3.56^{\mathrm{a}}$ & $15.1^{\mathrm{a}}$ & $26.2^{2}$ \\
\hline & $-1.33^{\mathrm{a}}$ & $-2.25^{\mathrm{a}}$ & $0.92^{\mathrm{a}}$ & $73.6^{\mathrm{a}}$ & $9.50^{\mathrm{a}}$ & 3.51 & $26.9^{\mathrm{a}}$ & $12.6^{\circ}$ \\
\hline Aronningle & $-1.30^{2}$ & $-2.35^{\mathrm{a}}$ & $1.05^{\mathrm{a}}$ & $77.1^{a}$ & $9.92^{\mathrm{a}}$ & $4.07^{\circ}$ & $14.1^{b}$ & $24.0^{\circ}$ \\
\hline
\end{tabular}

formation, Tyree and Richter 1981) and the following parameters were calculated according to Koide et al. (1989):

- ${ }^{100} \Psi_{\pi \text { : osmotic potential at full turgor, }}$

- ${ }^{0} \Psi_{\pi}$ : osmotic potential at turgor loss,

- $\Delta \Psi_{\pi}$. the amplitude of osmotic response $\left({ }^{100} \Psi_{\pi^{-}}\right.$ ${ }^{0} \Psi_{\pi}$ ), mostly determined by tissue elastic properties (i.e., low for rigid leaf tissue, Cheung et al. 1975),

- ${ }^{0}$ RWC: relative water content at turgor loss,

- $\varepsilon_{\mathrm{i}}$ : bulk modulus of elasticity calculated as the change of turgor with unit change in RWC $\left(\varepsilon_{i}=\right.$ $\mathrm{d} \Psi_{\mathrm{t}} / \mathrm{dRWC}$, Pavlik 1984) during the initial fast turgor loss, thus $\varepsilon_{\mathrm{i}}=\left[-(\mathrm{b} / \mathrm{a}) \mathrm{x}^{(-\mathrm{b}-1)}+\mathrm{c} /(\mathrm{cx}+\mathrm{d})^{2}\right] * 100$, where $\mathrm{x}=100$-RWC at the fastest loss of turgor, near to full turgidity, $\left(a x^{b}\right.$ is the equation of a curve, $c x+d$ is the equation of a line).

Since the estimation of apoplastic water content $\left(R_{a}\right)$ is not reliable in this way (Kubiske and Abrams 1990, Tyree and Richter 1981), we did not use this parameter. Although effort was made to remove all surface water from leaves after water saturation, for several species (e.g., Festuca spp. with inrolled leaves) this was not successful. This resulted in an initial plateau on the curve when RWC declined with no associated change in leaf water potential. Curves were corrected for this effect in the following way:

original RWC $=\left[\left(\mathrm{m}_{\mathrm{a}}-\mathrm{m}_{\mathrm{d}}\right) /\left(\mathrm{m}_{\mathrm{t}}-\mathrm{m}_{\mathrm{d}}\right)\right]^{* 100}$

corrected RWC $=\left[\left(\mathrm{m}_{\mathrm{a}}-\mathrm{m}_{\mathrm{d}}\right) /\left(\mathrm{m}_{\mathrm{t}}-\mathrm{m}_{\mathrm{p}}+0.0001-\mathrm{m}_{\mathrm{d}}\right)\right]^{*} 100$ where $m_{t}=$ mass at full turgor, $m_{p}=$ mass at the end of the plateau (until $\Psi$ does not change), $\mathrm{m}_{\mathrm{a}}=$ actual mass, and $\mathrm{m}_{\mathrm{d}}=$ dry mass.

In addition to $\mathrm{p}-\mathrm{V}$ analysis parameters, several related variables were determined for each species. A measure of potential transpiration rate (E) was obtained by determining the rate of water loss from fully turgid cut leaves (or leaf pieces) in a growth chamber (at $120 \mu \mathrm{mol} \mathrm{m}^{-2} \mathrm{~s}^{-1}$ photosynthetic photon flux density and $23-25^{\circ} \mathrm{C}$ air temperature). To characterize leaf structure, the specific leaf area (SLA, area per unit leaf dry mass) and the percentage proportion of dry matter in the water saturated leaf mass (DMP) were calculated. Specific leaf area has two components: leaf thickness and bulk tissue density. Although these parameters were not determined directly, leaf dry matter proportion measured in our study is closely related to tissue density and is independent of leaf thickness (Niinemets 1999, Wilson et al. 1999). Leaf area was determined to $\pm 0.1 \mathrm{~cm}^{2}$ by using a LI-COR 3100 Area Meter (LICOR Inc., Nebraska).

For each variable, analysis of variance (ANOVA) with subsequent least significant difference (LSD) tests were used for statistical evaluation by using the Statistica 4.5 package (StatSoft Inc. 1993). Differences were considered significant at $\mathrm{p}<0.05$ probability level. Additionally, multivariate statistical analysis of the full dataset was completed by the Centered Principal Components Analysis routine of the SYN-TAX 5.0 program package (Podani 1993). 


\section{Results and discussion}

The most marked differences in the species studied were between grasses and dicots. Osmotic potential at full turgor $\left({ }^{100} \Psi_{\pi}\right)$ and at turgor loss $\left({ }^{0} \Psi_{\pi}\right)$ was lower (more negative), while the amplitude of osmotic change in grasses was twice that in dicots (Table 2). Furthermore, grasses had more elastic leaf tissue (lower bulk elastic modulus, $\left.\varepsilon_{\mathrm{i}}\right)$, lower transpiration rate $(\mathrm{E})$, and higher specific leaf area (SLA) and leaf dry matter proportion (DMP) than dicots. These findings suggest that the osmotic component is more important in generating water potential gradients from leaf to soil in grasses, while the relatively inelastic cell walls of dicots allow this gradient to be achieved by a more rapid loss of turgor near full turgidity. This is clearly seen on the Höfler-diagrams presented for a representative species of dicots and grasses (Fig. 1). The grass Cynonon dactylon has lower osmotic and water potentials at a given RWC value and maintains turgor to a RWC lower than that in the dicot Achillea pannonica, which exhibits a more rapid drop in turgor. We assume that these patterns are at least partly associated with the differences in root system morphology and thus in the source of available water for the plant. The fibrous root system of steppe grasses primarily exploits the topmost soil layers (Jackson et al. 1996) where water is less readily available, and hence these plants develop a greater water potential gradient. In contrast, the taproot system of dicots may rely on the more readily available water that is stored deeper in the soil, and these plants can cope with temporary stress by steepening the water potential gradient by turgor loss alone. This strategy is less expensive than investment into osmotic substrates. Knapp and Medina (1999) came to a similar conclusion when compared rooting depth and dry season leaf water potential for dominant $\mathrm{C}_{4}$ grasses and subordinate $\mathrm{C}_{3}$ dicots in the tallgrass prairie. Owing to their root system morphology grasses may be capable of more efficient use of small rainfall events rewetting soil layers near surface than dicots (Sala and Lauenroth 1982). As far as the osmotic versus elastic component is concerned, Nilsen (1983) argued that although the rapid drop of water potential with water loss in rigid tissues generates a high leaf-to-soil water potential gradient, turgor becomes lost at moderate water deficits and growth stops. Instead, in seasonally dry environments - like our steppe grasslands - relatively elastic cell walls coupled with the ability to increase solute concentration in the cytoplasm (i.e., osmotic component) are the two attributes drought tolerant species should exhibit. In our study, the higher importance of the osmotic component in grasses (compared to dicots), their more elastic leaf tissue and reliance on drier soil strata supports this reasoning. Knapp (1984) experienced a similar relationship between drought tolerance and the osmotic vs. elastic components of leaf water potential when compared
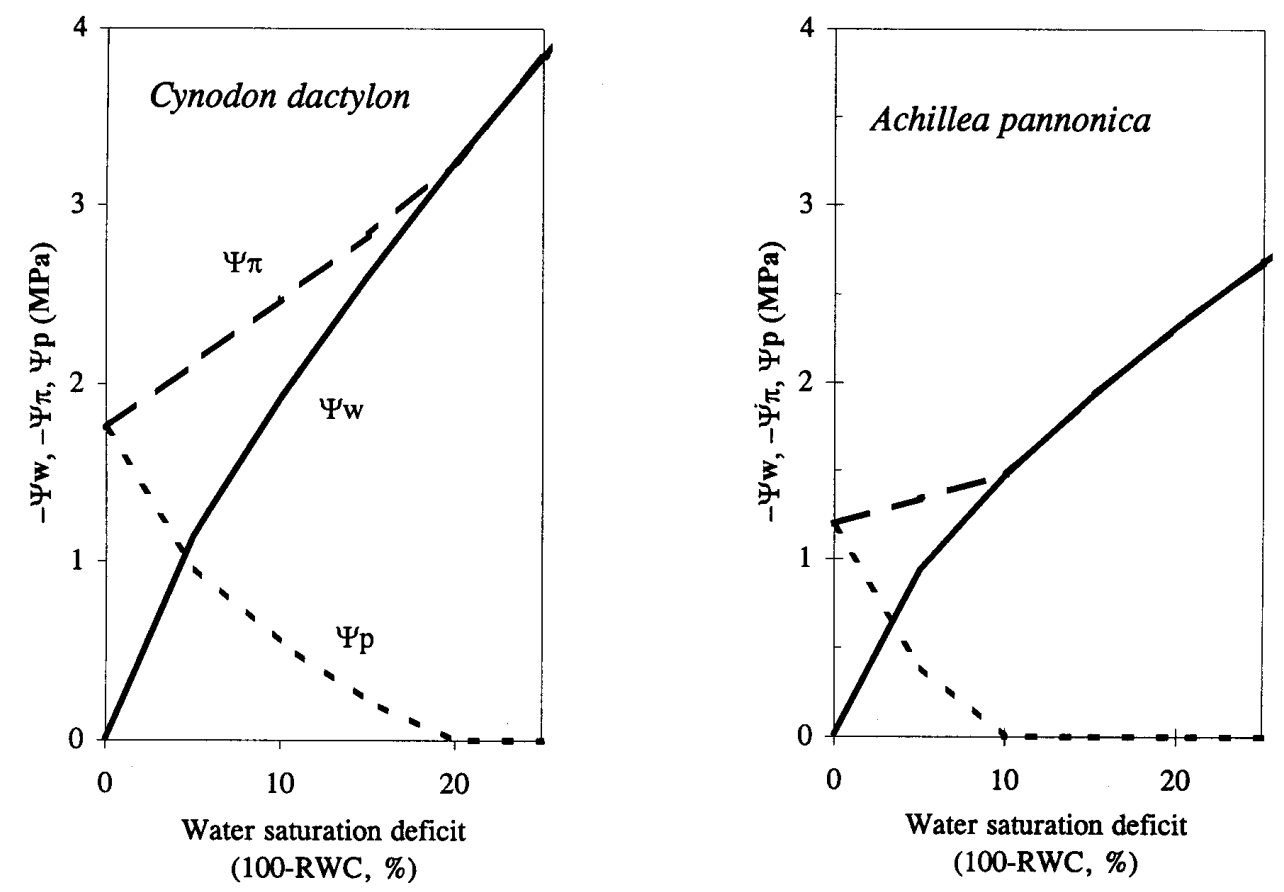

Figure 1. Höfler diagrams for a dicot (Achillea pannonica) and a grass (Cynodon dactylon) species as examples of their own groups. Abbreviations: $\Psi_{\mathrm{w}}$ : water potential; $\Psi_{\pi}$ : osmotic potential; $\Psi_{\mathrm{p}}$ : turgor potential. 


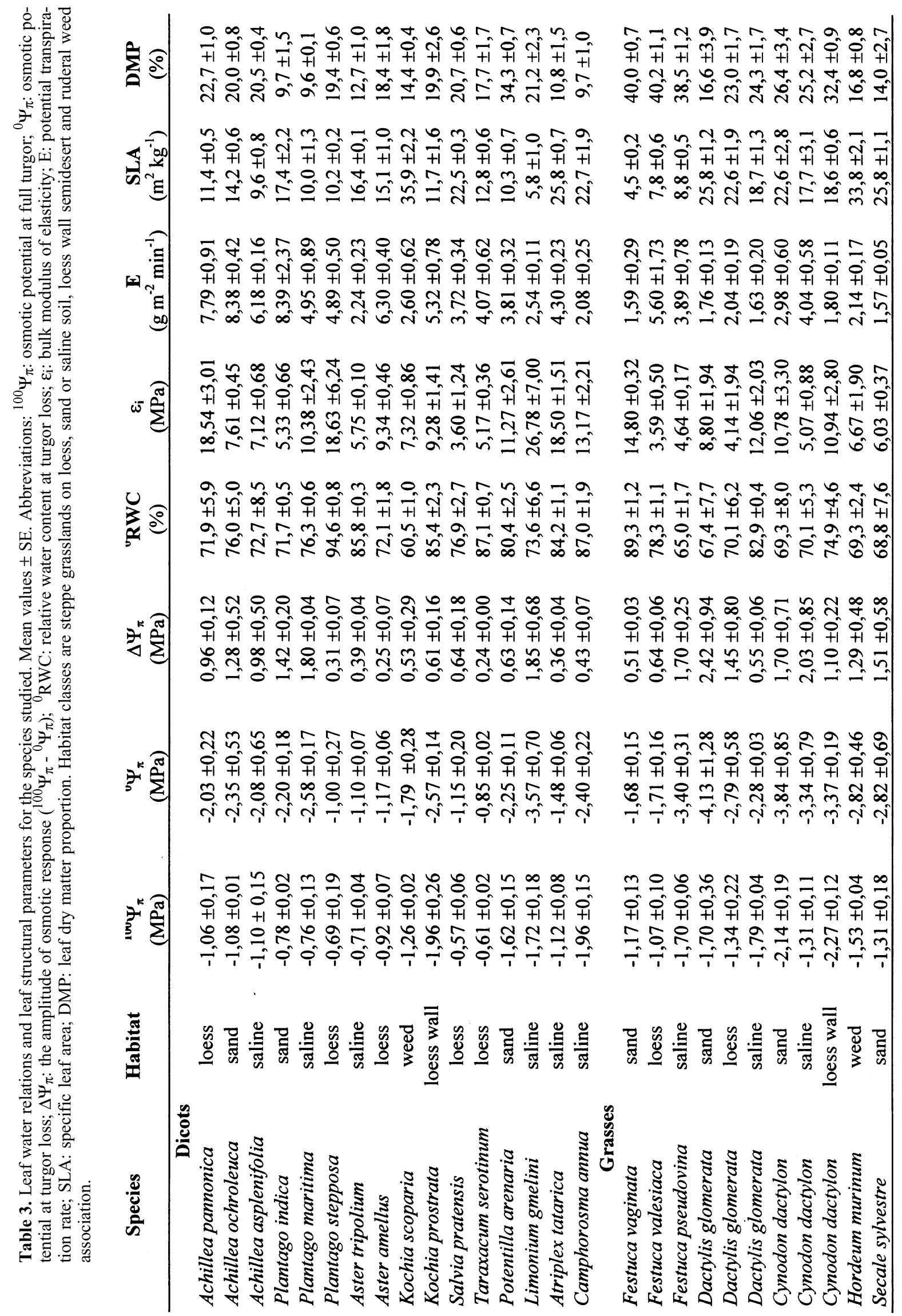


Figure 2. Osmotic potential at full turgor $\left({ }^{100} \Psi_{\pi}\right)$ for dicots and grasses in the four steppe habitats. Columns with the same letter are not significantly different.

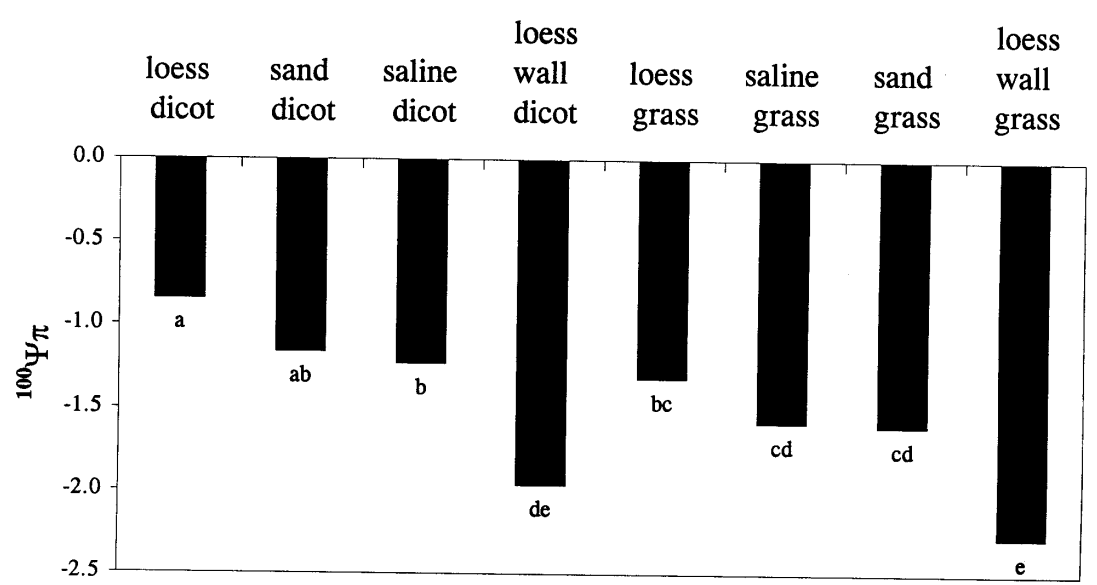

three tallgrass praire grass species. The relatively elastic walls of grasses allow the maintenance of positive turgor and hence growth at lower water content values (RWC at turgor loss is $73.2 \%$ and $78.5 \%$ for grasses and dicots, respectively, Table 2). However, the low osmotic potential means that the grasses must be tolerant to relatively high concentrations of osmotic substances in their cells, while dicots are less constrained in this respect. The grasses have thin leaves (high SLA) of relatively high density (high DMP), while the thicker and less dense leaves of dicots are built of less carbon (since density reflects the volume of apoplast (i.e., cell wall and support tissue) made of polysaccharides, Niinemets 1999). Note that these between-group differences hold true only for the set of species studied and are not representative of either grasses or dicots in general. In other studies, xerophytic grasses were found to possess relatively rigid leaf tissue, low SLA and low water potentials (Kalapos 1994, Loik and Harte 1997, Maxwell and Redmann 1978). As a group, the studied dicots were much more heterogeneous for the parameters studied than the grasses, most probably due to their greater variety of growth forms, ranging from xerophyllous to leaf succulent species. Among grasses, the three Festuca species had a more markedly different leaf structure than the other species, with cylindrical scleromorphic leaves that had the lowest SLA and the highest DMP (Table 3).

Habitat effects were less marked, significant differences appeared in osmotic parameters only. Osmotic potential at full turgor and at turgor loss decreased in the following order: loess grassland $>$ sand grassland $\cong$ saline grassland $>$ loess wall (Table 2), and this pattern was consistent within subgroups of species (i.e., among grasses and dicots, Fig. 2). The osmotic amplitude was the smallest in loess grassland, and the greatest in sand grassland.
Saline grassland and loess wall semidesert plants tended to have less elastic tissue (higher $\varepsilon_{i}$ ), lower transpiration rate (E) and SLA than loess and sand grassland species. The highest dry matter investment in building leaf tissue (DMP) occurred in loess wall species, the lowest in saline grasslands, while sand and loess grasslands were comparable intermediates, although the difference is not significant statistically. Thus, in accordance with habitat water regime, plants from the least dry loess grassland need the least steep water potential gradient to extract water from soil (high osmotic potential values), use water less sparingly (high E) and possess the most 'mesic-like' leaf structure (relatively large surface, elastic tissue). The loess wall semidesert represents the dry end of the gradient, where leaf osmotic potentials $\left({ }^{100} \Psi_{\pi}\right.$ and $\left.{ }^{0} \Psi_{\pi}\right)$ are indeed the lowest, leaf dry matter proportion is the highest, while in other parameters it does not differ from the also relatively dry saline steppe. The two leaf structural parameters, SLA and DMP change in a different way among habitats, as it was already found for woody (Niinemets 1999) and herbaceous (Wilson et al. 1999) plants. For example, the equally low leaf area per unit dry mass (i.e., SLA) of loess wall and saline grassland plants is caused by different structure, i.e., by high tissue density in the xeric leaves of loess wall species, while by relatively high leaf thickness in the low-density succulent leaves of saline grassland species (Table 2).

Life form influenced leaf structure, but had no measurable effect on water relations. Annuals had much higher SLA and lower DMP than perennials (Table 2). This is because the shorter-lived foliage of annual species is thinner and cheaper in terms of invested dry matter than that of the longer-lived leaves of perennials. Differences in structural parameters between annuals and perennials were more marked than between grasses and dicots. 


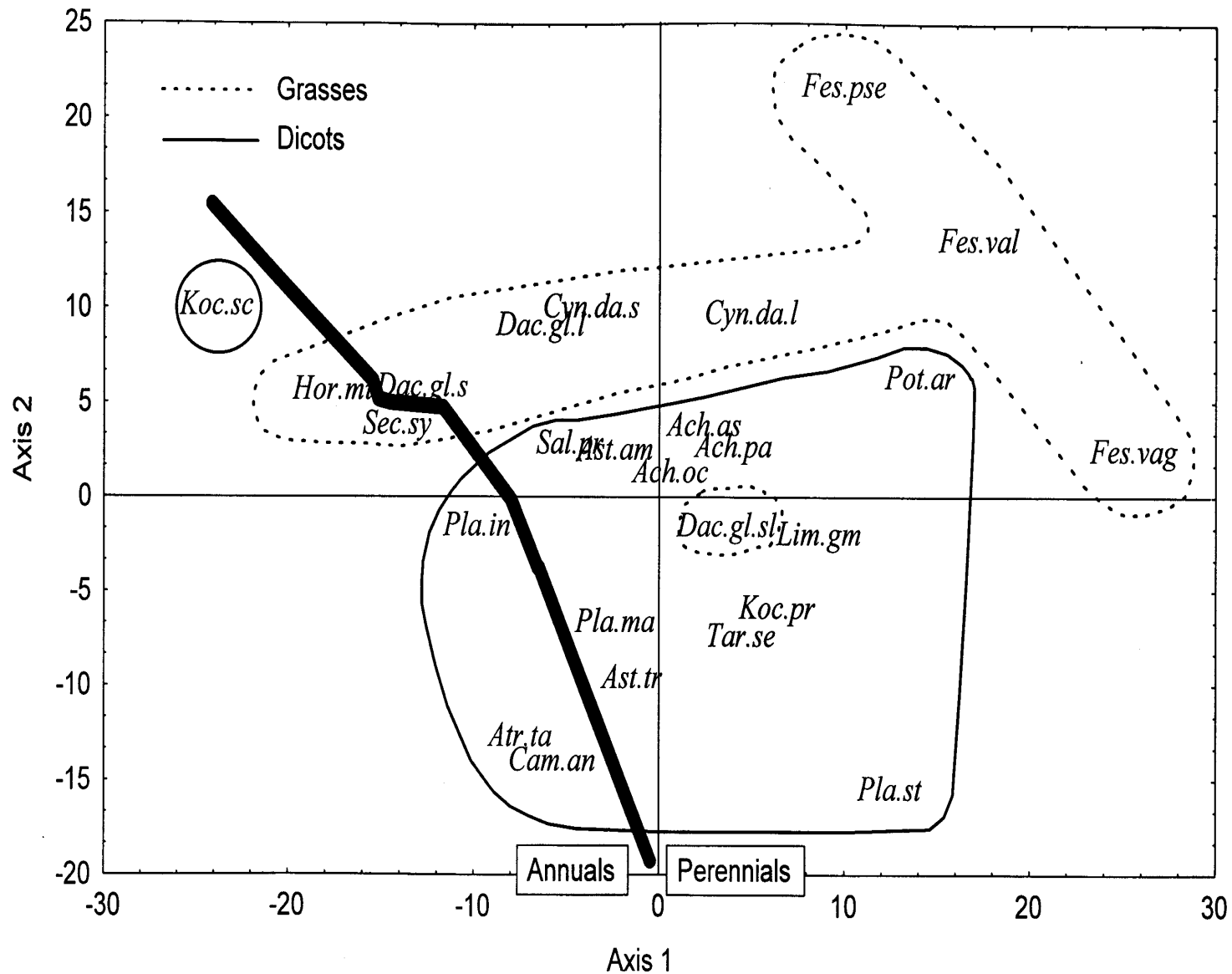

Figure 3. Ordination diagram of the species studied (Centered PCA). Species are coded with the first three letters of the genus name plus the first two or three characters of the species name (e.g., Fes.vag = Festuca vaginata). For the two habitat generalist grasses (Cynodon dactylon and Dactylis glomerata) abbreviation for habitat type follows the species code, where $.1=$ loess, $. \mathrm{s}=$ sand, and $. \mathrm{sl}=$ saline steppe. The thick diagonal line separates annuals and perennials. For species names see Table 1.

The multivariate analysis of all studied parameters resulted in a fair segregation of grasses and dicots in the ordination space (with only one outlier for each group, Fig. 3). This segregation mainly comes from the osmotic vs. turgor component dominance dichotomy discussed earlier, since mainly the $\mathrm{pV}$-analysis parameters are responsible for that. The contribution of original parameters to principal components was such that the first PCA axis was associated almost exclusively with structural variables (SLA, DMP, ${ }^{0} \mathrm{RWC}, \varepsilon_{\mathrm{i}}$ ), while the second axis was mainly associated with $\mathrm{pV}$-analysis parameters $\left({ }^{0} \Psi_{\pi}\right.$, ${ }^{100} \Psi_{\pi}$ ), although certain structural variables also had some contribution (Fig. 4). In a similar study, Bannister (1986) also found leaf structural variables and $\mathrm{pV}$-analysis parameters to influence different PCA ordination axes. The segregation of Kochia scoparia and saline grassland Dactylis glomerata from their own groups is mostly caused by an outlier ${ }^{0}$ RWC value. Furthermore, annuals and perennials fully segregate along the first PCA axis, which is predominantly associated with the structural parameter, SLA. However, neither grasses nor dicots form a compact group, and dicots display the greatest heterogeneity. Among grasses, sclerophyllous Festuca species with high-density terete leaves segregate sharply from flat-leaved species, but themselves are also quite different. The sand-dweller Festuca vaginata with highly rigid leaf tissue differs markedly from $F$. pseudovina from the salt affected grassland which has a high osmotic component, while $F$. valesiaca from loess grassland is intermediate between the two (Fig. 3, Table 3). For the complete data set, the three steppe types do not segregate in the ordination space (figure not shown).

Data for each species are given in Table 3. For habitat specialist species within the same genus, it appears that difference in leaf water relations is not significant statistically for certain congeners (Achillea and Aster, although the two Aster species are placed quite apart in the ordination space, Fig. 3). The absence of significant differences 
Figure 4. Correlations of the original variables with the first two principal components in centered PCA. For abbreviations, see Table 2 .

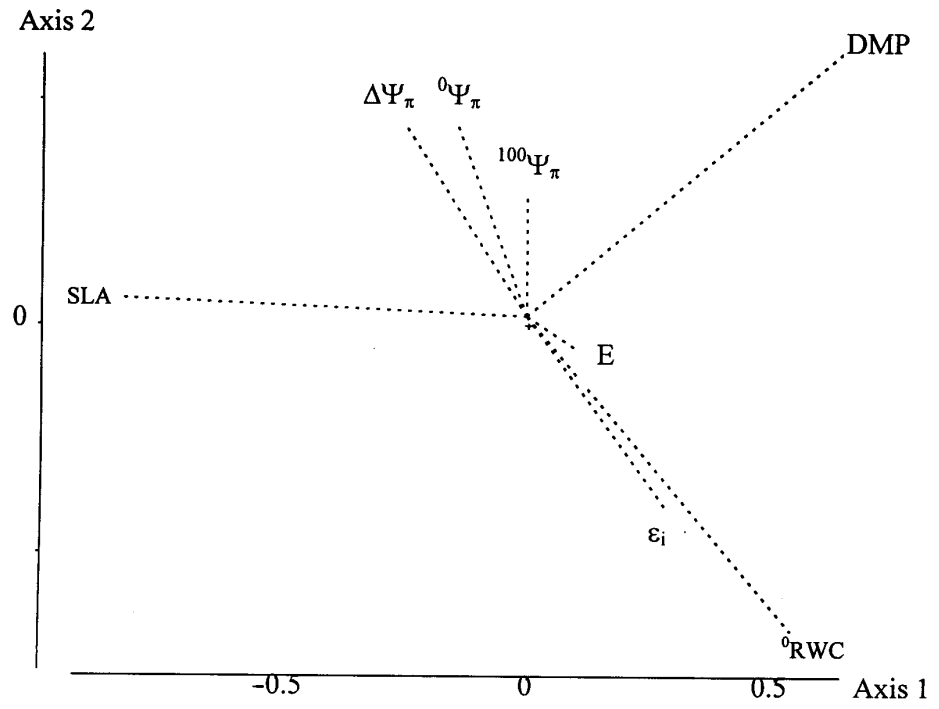

suggests that these congeners might rely on similar water supply in the three steppe grasslands. In contrast, the Festuca, Kochia and Plantago species from habitats with dissimilar water regimes differed significantly, thus leaf function and associated structure in these congeners must be different to ensure survival in their own habitat. For the two generalist grasses (Cynodon dactylon and Dactylis glomerata), habitat-specific populations showed a tendency of increasing capacity for water extraction from soil (more negative water potential) with increasing habitat dryness, although differences were significant only between the two extremes of the water availability gradient (Table 3).

\section{Conclusions}

It appears that in the studied steppe habitats no generalization can be made on how leaf water relations change with water availability. Several specialist congeners and two generalist grasses showed a capacity for generating greater soil-to-plant water potential gradient with increasing habitat dryness, which in turn enables them to take up water from less easily available source. However, for other habitat specialists no substantial differences were observed in leaf water relations. These plants might occupy microsites with similar water regime, and/or other habitat or plant properties have more profound influence on their ecological distribution than water relations do. For the whole species set, life form (annual or perennial) and rough taxonomic affiliation (dicot or grass) have a more profound influence on leaf water relations and/or associated structural properties than habitat type.
Acknowledgments: This study was supported by the Hungarian Scientific Research Fund (OTKA F22728), and the Ministry of Education (FKFP 105/1997 and 353/2000). We thank Emese Balogh for her assistance in laboratory measurements. Two anonymous referees greatly contributed to the improvement of the manuscript

\section{References}

Bannister, P. 1986. Drought resistance, water potential and water content in some New Zealand plants. Flora 178: 23-40.

Bowman,W.D. and S.W. Roberts. 1985a. Seasonal and diurnal water relations adjustments in three evergreen chaparral shrubs. Ecology 66: 738-742.

Bowman,W.D. and S.W. Roberts. 1985b. Seasonal changes in tissue elasticity in chaparral shrubs. Physiol. Plant. 65: 233-236.

Cheung, Y.N.S., M. T. Tyree and J. Dainty. 1975. Water relations parameters on single leaves obtained in a pressure bomb and some ecological interpretations. Can. J. Bot. 53: 1342-1346.

Fekete, G., Zs. Molnár and F. Horváth. 1997. Description, identification key, and classification for habitats in Hungary and the National Habitat Classification System. Magyar Természettudományi Múzeum, Budapest. [in Hungarian]

Grammatikopoulos, G. 1999. Mechanisms for drought tolerance in two Mediterranean seasonal dimorphic shrubs. Aust. J. Plant Physiol. 26: 587-593

Jackson, R.B., J. Canadell, J. R. Ehleringer, H. A. Mooney, E.O.Sala, and E. D. Schulze. 1996. A global analysis of root distributions for terrestrial biomes. Oecologia 108: 389-411.

Kalapos, T. 1994. Leaf water potential - leaf water deficit relationship for ten species of a semiarid grassland community. Plant and Soil 160: 105-112.

Knapp, A.K. 1984. Water relations and growth of three grasses during wet and drought years in a tallgrass prairie. Oecologia 65 : 35-43.

Knapp, A.K. \& E. Medina. 1999. Success of C4 photosynthesis in the field: lessons from communities dominated by $\mathrm{C}_{4}$ plants. In: R.F. Sage and R.K. Monson (eds), C4 plant biology. Academic Press, San Diego, 251-283. 
Koide, R. T., R. H. Robichaux, S.R. Morse and C. M. Smith. 1989. Plant water status, hydraulic resistance and capacitance. In: R.W. Pearcy, J. Ehleringer, H.A. Mooney and P.W. Rundel (eds), Plant physiological ecology. Field methods and instrumentation. Chapman and Hall, London. pp. 168-173.

Kubiske, M. E. and M. D. Abrams. 1990. Pressure volume relationship in non-rehydrated tissue at various water deficits. Plant, Cell Envir. 13: 995-1000.

Kvet, J. and M. Rychnovská. 1965. Contribution to the ecology of the steppe vegetation oh the Tihany peninsula. II. Water retention capacity of some characteristic grass and forb species. $A n$ nal. Biol. Tihany 32: 275-288.

Lo-Gullo, M.A. and S. Salleo. 1988. Different strategies of drought resistance in three Mediterranean sclerophyllous trees growing in the same environmental conditions. New Phytol. 108: 267276.

Loik, M.E. and J. Harte. 1997. Changes in water relations for leaves exposed to a climate-warming manipulation in the Rocky Mountains of Colorado. Env. Exp. Bot. 37: 115-123.

Maxwell, J. O. and R. E. Redmann. 1978. Leaf water potential, component potentials and relative water content in a xeric grass, Agropyron dasystachyum (Hook.) Scribn. Oecologia 35: 277284.

Muller, R. 1991. Growing season water relations of Rhododendron maximum L. and Kalmia latifolia L. Bull. Torrey Bot. Club 118: 123-127.

Niinemets, Ü. 1999. Components of leaf dry mass per area - thickness and density - alter leaf photosynthetic capacity in reverse directions in woody plants. New Phytol. 144: 35-47.

Nilsen, E.T., M. R. Sharifi, P.W. Rundel, W. M. Jarrell \& R. S. Virginia. 1983. Diurnal and seasonal water relations of the desert phreatophyte Prosopis glandulosa (Honey mesquite) in the Sonoran Desert of California. Ecology 64: 1381-1393.

Nobel, P.S. and P. W. Jordan. 1983. Transpiration stream of desert species: resistances and capacitances for a $\mathrm{C}_{3}, \mathrm{C}_{4}$ and CAM plant. J. Expt. Bot. 34: 1379-1391.

Pavlik, B.W. 1984. Seasonal changes of osmotic pressure, symplasmic water content and tissue elasticity in the blades of dune grasses growing in situ along the coast of Oregon. Plant Cell Env. 7: 531-539.
Podani, J. 1993. SYN-TAX-pc. Computer programs for multivariate data analysis in ecology and systematics. Version 5.0. User's guide. Scientia Publishing, Budapest.

Prior, L.D. and D. Eamus. 1999. Seasonal changes in leaf water characteristics of Eucalyptus tetrodonta and Terminalia ferdinandiana saplings in a Northern Australian Savanna. Aust. J. Bot. 47: 587-599.

Rascio, A., M. C. Cedola, G. Sorrentino, D. Pastore and G. Wittmer. 1988. Pressure-volume curves and drought resistance in two wheat genotypes. Physiol. Plant. 73: 122-127.

Sala, O.E. and W.K. Lauenroth. 1982. Small rainfall events: an ecological role in semiarid regions. Oecologia 53: 301-304.

Soó, R. 1964. Synopsis systematico-geobotanica florae vegetationisque Hungariae I. Akadémiai Kiadó, Budapest. [in Hungarian]

Tyree, M.T., N. S. Cheung, M.E. MacGregor, and A.J.B. Talbot. 1978. The characteristics of seasonal and ontogenetic changes in the tissue water relations of Acer, Populus, Tsuga and Picea. Can. J. Bot. 56: 635-647.

Tyree, M.T. and H. Richter. 1981. Alternative methods of analysing water potential isotherms: some cautions and clarifications. $J$. Exp. Bot. 32: 643-653.

Varga, Z. 1998. Steppe-like grasslands in Hungary: Conservation and sustainable use. In: G. Nagy (ed.), Ecological Aspects of Grassland Management, Grassland Science in Europe, Vol. 1. Proceedings of the $17^{\text {th }}$ General Meeting of the European Grassland Federation, Debrecen, Hungary. Debrecen, pp: 299-311.

Wan, C., R.E. Sosebee and B.L. McMichael. 1993. Drought-induced changes in water relations in broom snakeweed (Gutierrezia sarothrae) under greenhouse- and field-grown conditions. Env. Exp. Bot. 33: 323-330.

Wilson, P.J, K. Thompson and J.G. Hodgson. 1999. Specific leaf area and leaf dry matter content as alternative predictors of plant strategies. New Phytol. 143: 155-162.

Zólyomi, B. and G. Fekete. 1994. The Pannonian loess steppe: differentiation in space and time. Abstracta Botanica 18: 29-41. 